\title{
Shallow Analysis on Skill Training in Painting Teaching and Cultivation of Thinking Method
}

\author{
Fu Jinyangzi
}

Fine Arts Department, Arts and Media College, Bohai University, Jinzhou, China

Keywords: painting teaching; skill training; cultivation of thinking method

\begin{abstract}
Painting is the key content of art education in colleges and universities, so improving the painting teaching is of great help to the cultivation of outstanding art talents in the country. Combined with teaching practice and experience, this paper analyzes problems existing in painting teaching in colleges and universities, and puts forward methods of strengthening skill training in painting teaching and the cultivation of art thinking method, hopefully to provide reference for the implantation of painting teaching in colleges and universities.
\end{abstract}

From technological perspective, painting is a process of adding color on certain supporting surface, which can be paper or cloth, and tools to add color can be paintbrush, sponge or cloth strips From art language, the significance of painting is to express concept or meaning that painters want to express with patterns, compositions and other artistic methods. Painting is a part of fine arts, and painting course is basic course of fine arts specialty in colleges and universities. Teachers are required to teach students to grasp various painting skills, application law, and relevant theoretical knowledge of painting, and to enlighten and cultivate students' aesthetic consciousness and art thinking, and to encourage students, from passive acceptance to active cognition, to master the law in painting and correctly and independently apply the law to painting creation, which requires teachers to continuously improve teaching methods, enhance the flexibility and pioneering feature of teaching, and to grasp the benign circulation relationship between complementing teaching and learning.

\section{Problems in Painting Teaching in Colleges and Universities}

\subsection{The lack of teaching practice activities, and grasping of painting skills}

At present, many colleges and universities have built promotion mechanism for teaching staff, whereas, the standard to assess the promotion of teaching staff is students' test scores and classroom efficiency. Many art teachers tend to focus on art teaching in classroom in order to obtain higher remuneration or promotion opportunities. They expect students to have excellent performance in the classroom, but rarely lead students to sketch in the natural environment, and fail to provide the opportunity for students to participate in the practice of painting design, thus, most students lack the experience of actual painting design, so the mastery of some skills in painting is not in place.

\subsection{The simple teaching mode}

In order to better cultivate students' painting ability, some teachers carry out teaching activities according to teaching materials, and use textbooks as the main material for teaching painting. At the same time, many painting teachers always take the conventional teaching methods when they teach art students, first teachers explain the theoretical knowledge of the painting art to students, students understand some basic painting principles, and then students perform painting-imitating according to samples provided by teachers. But painting requires certain imagination and creativity. Without imagination, painting is a soulless, and excellent paintings cannot be created. For art students, if teachers always adopt a fixed pattern and the old-fashioned method of teaching painting, they would not only gradually lose interest in learning painting, but also cannot develop artistic thinking, which is very unfavorable for cultivating students' painting ability and thinking methods. 


\section{Strategies of Strengthening Skill Training in Painting Teaching and Cultivation of Thinking Method}

\subsection{To enhance the observation ability and train painting skill}

In order to effectively train students' skill in painting, teachers are required to focus on the cultivation of students' observation ability in teaching painting. And for students, the learning of painting not only include painting content, also include painting skills. Therefore, for college students with certain painting basis and ability, the strengthening of observation ability is the key to improving painting skill, which shall be emphasized in painting.

First of all, college students shall observe the object comprehensively and carefully, including external characteristics and internal features of the object, so as to paint more similar works, which can enhance students' patience and increase students' observation ability. Therefore, in teaching, art teachers encourage students to observe various different objects and paint, including various objects in our daily life, such as certain building around students and campus. Students shall observe carefully in painting, and show characteristics of objects they paint from various perspectives so as to ensure the similarity of painting works.

Secondly, when cultivating students' observation ability, art teachers of colleges and universities should focus on the teaching of painting skills for students, including the composition and angle of the painting, which is the most important part of the teaching. College students should also carefully take their notes in the process of painting teaching, and should constantly practice the painting skills they have mastered and effectively improve their painting skills effectively.

\subsection{To fully understand color space and grasp painting skills}

Painting includes many steps such as composition, pattern starting, and coloring. Color is an important part of the whole painting. The understanding of color space are especially important in when students learning painting. Color space in a broad sense, is that the human eye has different feelings for rays of light with different frequencies, also known as color gamut. Color space today are understood by one-dimensional and two-dimensional coordinates, which can usually express three-dimensional things. This paper explains color space from three perspectives. First of all, color space is built on eye viewing and tactual space. Eye viewing is also an intuitive visual experience, which is communicated to the brain through both eyes. For example, colors will be different for different distance. The color is mainly small and fuzzy for a far distance, whereas, the visual information is mostly true and clear in closer distance. The tactual space of color space is usually the subjective feeling of the brain spirit, that is, the emotion-related color change that occurs through the brain after visual communication. The color touched by the spiritual touch is subjective feelings and emotional fluctuations, that is, the understanding of color connotation is more closely related to the subjective feelings of color and spirit. For students, most of students can easily enter the visual experience of watching with both eyes. The visual color space is relatively simple and easy to accept, and the tactual space needs to be cultivated for a long time. Secondly, color space is closely related to light. The beauty of color can be different through the illumination of light. The same color can be changed into different colors under different light. The dim light will make the color dim and dull, and the soft light will make the color becomes soft and warm, which is because with the illumination of light, the color reacts with the light during the mapping, making the color blend with the light. Third, students can start with the color contrast. Color contrast is easier to understand, because it is the innate ability of everyone, and the instinct of human perception of beauty. The color contrast is to observe the difference by observing the colors of the two different effects. In actual painting, the color difference is changed by contrast, and the best color is selected by observation to achieve the perfect requirement of the painting.

\subsection{To implement the sketch teaching with comprehensive teaching mode}

In sketch teaching, college teachers shall not only teach basic knowledge in books to students, also fully combine with objects in daily life to encourage students to create works based on real things, which is conductive to widening students' thinking, enhancing the speed of sketching and 
ensuring the quality of works.

First of all, art teachers should inform students the method to observe the structure of the plaster figure in advance. In the process of observation, it is necessary to not only understand the overall structure of the plaster figure, but also the detailed parts such as the eye and the mouth. Overall and meticulous parts are grasped so that the perfect sketch is created.

Secondly, art teachers should also guide students to analyze the overall proportion of plaster figure, and analyze how to adjust the degree of light and darkness of sketch works, and enhance the layering and stereoscopic degree of the works, so that people can grasp the excellence of the works at a glance. In addition, it is relatively boring to cultivate painting skills. Therefore, it is necessary to enhance the fun of the learning process in teaching. For instance, teachers should organize real-life models to carry out painting training after students mastering painting skills. In sketch exercises with real-life models, teachers should not only encourage students to focus on the overall proportion and light and shadow of real-life models, but also should pay attention to the portraits of plaster figures, and draw the subtle expressions and manners of the models into the sketch works to make the picture of the whole works more vivid.

\subsection{To fully develop the imagination and cultivate art thinking}

In order to better train students to master painting skills and cultivate good art thinking, it is necessary to fully develop the creativity and imagination of students in the teaching of painting, develop the self-spirit of students, and encourage students to think independently and have independent painting skills. Previous teaching methods simply taught by teachers cannot meet the needs of painting in new era. Painting teaching in new era needs to make students become the dominant one in the learning process. For instance, in colleges and universities of Europe and the United States, professors often give some associative topics to students to practice. Generally, they only give a few concepts that seem to have nothing to do with each other to comprehensively develop the association and imagination of students and combine these concepts and show it through painting, which can fully develop the imagination of students and enable give full paly to the creativity of students' art thinking. Therefore, teachers shall pay attention to cultivating students' creative ability, and make art thinking education become the key content of painting education in new era.

\section{Conclusion}

This paper analyzes the effective strengthening of skill training in painting teaching and cultivation of art thinking, mainly to develop students' painting ability and lay a foundation for students to grasp more painting knowledge and work. Under the effective guidance of teachers, college students can grasp more painting skills and cultivate art thinking so as to effectively improve their painting competence.

\section{References}

[1] Ma Rui, Wang Chunlei. Shallow Analysis on Innovation and Reform in Fine Art Teaching of Art Design Major in Higher Vocational Colleges [J]. Course Education Research, 2017.

[2] Wu Xiangdong, Liu Yongcai. Shallow Analysis on Fine Art Basic Teaching of Art Design Major in Higher Vocational Colleges [J]. Master, 2011.

[3] Ma Chunxing. The Problem and Reflection on Chinese Painting Teaching from Traditional Perspective [J]. Journal of Hebei Normal University of Science \& Technology (Social Sciences), 2014.

[4] Wu Fang. On Innovative Research Reform of Learning Methods in Fine Art Teaching in Colleges and Universities [J]. Shaanxi Education (Higher Education), 2016.

[5] Xie Mingli. How to Improve Effectiveness of Public Art Painting Teaching in Colleges and Universities [J]. Art Education Research, 2017.

[6] Zheng Liqin. Focus on the Cultivation of Interests in Painting -To Position the Specialty and 
Humanity of Teaching of Painting Major in Colleges and Universities from Art History [J]. Art Education Research, 2017. 